\title{
Effect of the leukotriene receptor antagonist pranlukast on cellular infiltration in the bronchial mucosa of patients with asthma
}

Yutaka Nakamura, Makoto Hoshino, Jae Joon Sim, Koji Ishii, Kimio Hosaka, Teruo Sakamoto

\begin{abstract}
Background-It has been reported that pranlukast reduces the antigen induced immediate and late phase asthmatic responses, airway hyperreactivity to acetylcholine, and pulmonary eosinophil accumulation in guinea pigs. A study was undertaken to test the hypothesis that pranlukast may reduce the number of inflammatory cells in the bronchial mucosa of patients with asthma.

Methods-A double blind, placebo controlled study was performed in 17 mild to moderate asthmatic subjects to examine changes in inflammatory cell infiltration in response to pranlukast $(225 \mathrm{mg}$ orally twice per day for four weeks). Comparisons of the mean daily $\beta_{2}$ agonist use, symptom score, $\mathrm{FEV}_{1}$ percentage predicted, and airway methacholine responsiveness were made before and after treatment. Using fibreoptic bronchoscopy, bronchial biopsy specimens were obtained before and after treatment with either pranlukast $(n=10)$ or placebo $(n=$ 7). Immunohistology was performed using monoclonal antibodies for CD3, CD4, CD8, CD68, NP57, AA1, EG1, EG2, $\gamma$ GTP and CD19.
\end{abstract}

Internal Medicine, Toho University School of Medicine, 6- 11- 1 Ohmorinishi, Ohta-ku, Tokyo 143, Japan

Y Nakamura

M Hoshino

J J Sim

K Ishii

K Hosaka

Department of

Trauma and Critical

Care Medicine,

Kurume University

School of Medicine, 67 Asahi-machi,

Kurume-shi, Fukuoka

830, Japan

T Sakamoto

Correspondence to: Dr Y Nakamura,

Meakins-Christie

Laboratories, McGill

University, 3626 St Urbain

Street, Montreal, Canada

$\mathrm{H} 2 \mathrm{X} 2 \mathrm{P} 2$.

Received 6 October 1997

Returned to authors

9 December 1997

Revised version received

12 February 1998

Accepted for publication

20 May 1998
Results-When the pranlukast and placebo treated groups were compared there were decreases in $\beta_{2}$ agonist use, symptom score, and airway methacholine responsiveness after pranlukast but no increase in $\mathrm{FEV}_{1}$ was seen. The clinical response in patients treated with pranlukast was accompanied by a reduction in CD3 (median difference $-37,95 \%$ confidence interval (CI) -69 to -1 ; p $<0.05$ ), CD4 (median difference $-28,95 \%$ CI -49 to -8 ; p $<0.01$ ), AA1 (median difference $-15,95 \%$ CI -26 to $0 ; p<0.05)$ and EG2 positive cells (95\% CI -35 to 0 ; p<0.05), but not in EG1 positive eosinophils, $\gamma$ GTP positive cells, and CD19 positive plasma cells.

Conclusions-These results support the view that pranlukast may act by inhibition of bronchial inflammation in patients with asthma.

(Thorax 1998;53:835-841)

Keywords: leukotriene receptor antagonist; asthma; pranlukast

Bronchial asthma is a chronic inflammatory disease associated with infiltration of eosi- nophils, mast cells, and $\mathrm{T}$ lymphocytes into the airway wall. ${ }^{1}$ Cysteinyl leukotrienes (LTC4, LTD4 and LTE4), which are released from inflammatory cells, are potent bronchoconstrictor agents, ${ }^{23}$ increase vascular permeability, and may contribute towards the development of mucosal oedema ${ }^{45}$ and excessive mucus secretion. ${ }^{6}$ Furthermore, increased levels of leukotrienes have been reported in the sputum, urine, bronchoalveolar lavage fluid, plasma, and nasal secretions of asthmatic patients. $^{7-11}$ As such, therapeutic strategies designed to limit the production and/or release of these mediators have attracted considerable attention in the treatment of bronchial asthma.

In vitro studies have shown that pranlukast antagonises the action of LTC4, LTD4 and LTE4 within the airway. ${ }^{12}$ We hypothesised that the clinical action of pranlukast is a result of its ability to reduce the inflammatory cells within the airways of asthmatic subjects. We have therefore undertaken a double blind placebo controlled trial in patients with atopic asthma to assess the effect of pranlukast on immunocytochemical markers of airways inflammation. To delineate the action of this drug on leukotriene metabolism we also examined the ability of pranlukast to activate $\gamma$ GTP. In addition, we have correlated its effect on the airway mucosa with changes in airways responsiveness to methacholine and forced expiratory volume in one second $\left(\mathrm{FEV}_{1}\right)$.

Table 1 Clinical data of patients

\begin{tabular}{llcll}
\hline Age & Sex & $\begin{array}{c}\text { Total IgE } \\
\text { (IU/ml) }\end{array}$ & $\begin{array}{l}F E V_{I} \\
\text { (\% pred) }\end{array}$ & $\begin{array}{l}\text { Dmin } \\
\text { (unit) }\end{array}$ \\
\hline Pranlukast & & & & \\
26 & $\mathrm{M}$ & 2109.6 & 68.9 & 0.34 \\
39 & $\mathrm{M}$ & 2675.4 & 76.7 & 2.37 \\
20 & $\mathrm{~F}$ & 855.8 & 92.5 & 2.136 \\
41 & $\mathrm{M}$ & 3137.0 & 84.1 & 0.39 \\
35 & $\mathrm{M}$ & 634.3 & 57.8 & 0.135 \\
43 & $\mathrm{~F}$ & 706.0 & 72.1 & 0.282 \\
30 & $\mathrm{M}$ & 1021.3 & 63.7 & 2.995 \\
35 & $\mathrm{M}$ & 226.6 & 94.2 & 11.823 \\
36 & $\mathrm{M}$ & 439.5 & 62.0 & 1.042 \\
26 & $\mathrm{M}$ & 254.8 & 68.6 & 2.214 \\
Median & & 780.9 & 70.5 & 1.589 \\
35 & & & & \\
Placebo & & & & \\
34 & $\mathrm{~F}$ & 1109.2 & 81.3 & 1.51 \\
22 & $\mathrm{M}$ & 748.3 & 87.3 & 0.28 \\
36 & $\mathrm{~F}$ & 943.9 & 52.1 & 0.2 \\
32 & $\mathrm{~F}$ & 545.1 & 86.5 & 0.73 \\
23 & $\mathrm{M}$ & 385.7 & 79.7 & 0.45 \\
40 & $\mathrm{M}$ & 4528.6 & 68.5 & 0.15 \\
25 & $\mathrm{~F}$ & 368 & 64.4 & 9.05 \\
Median & & & & \\
32 & & 748.3 & 79.7 & 0.45 \\
\hline
\end{tabular}

$\mathrm{FEV}_{1}=$ forced expiratory volume in one second $;$ Dmin $=$ minimum dose of methacholine required to induce airways responsiveness. 
Table 2 Change in patient reported end points

\begin{tabular}{|c|c|c|c|c|c|c|c|}
\hline & \multicolumn{3}{|c|}{ Pranlukast $(n=10)$} & \multicolumn{3}{|c|}{ Placebo $(n=7)$} & \multirow[b]{2}{*}{$\begin{array}{l}\text { Estimated median } \\
\text { difference }(95 \% C I)\end{array}$} \\
\hline & Before & After & $\begin{array}{l}\text { Median } \\
\text { difference }\end{array}$ & Before & After & $\begin{array}{l}\text { Median } \\
\text { difference }\end{array}$ & \\
\hline$\beta_{2}$ agonist use (puffs/day) & 3.6 & 2.3 & $1.4^{\star \star}$ & 3.6 & 3.1 & 0.3 & $-1.4(-2.4 \text { to }-4)^{\star \star}$ \\
\hline Symptom score (scores/day) & 7.6 & 4.9 & $2.9^{\star}$ & 7.9 & 8.0 & -0.6 & $-3.3(-5.6 \text { to }-1.4)^{\star \star}$ \\
\hline $\mathrm{FEV}_{1}(\%$ pred $)$ & 70.5 & 77.2 & -3.5 & 79.7 & 76.5 & 1.1 & $4.6(-6.1$ to 16.8$)$ \\
\hline Dmin (units) & 1.59 & 5.89 & $-1.87^{\star}$ & 0.45 & 0.40 & -0.03 & $1.77(0.45 \text { to } 10.0)^{\star}$ \\
\hline
\end{tabular}

Values are medians. Within groups the Wilcoxon signed rank test was used to give median differences. Comparison of treatment effects was by Mann-Whitney U test on delta values (after treatment minus before treatment) for pranlukast versus placebo treatment.

${ }^{\star} \mathrm{p}<0.05 ;{ }^{\star \star} \mathrm{p}<0.01$

\section{Methods}

PATIENTS

Twenty one subjects were recruited from Toho University Hospital. All fulfilled the American Thoracic Society (ATS) criteria for asthma, ${ }^{13}$ had typical clinical symptoms, documented airways reversibility, and increased airways responsiveness to methacholine. The study was approved by the ethics committee of our institute and informed consent was obtained from all patients before entry into this study.

None of the patients had received inhaled or oral corticosteroids, or any other antiinflammatory medication such as disodium cromoglycate, nedocromil sodium, or theophylline within the previous four months. Ten of the subjects took intermittent $\beta_{2}$ agonists only when necessary. All patients were atopic as defined by a positive skin prick test to one or more common aeroallergens. Additional antigen inhalation tests were carried out with antigens to ensure their atopic status. The antigen

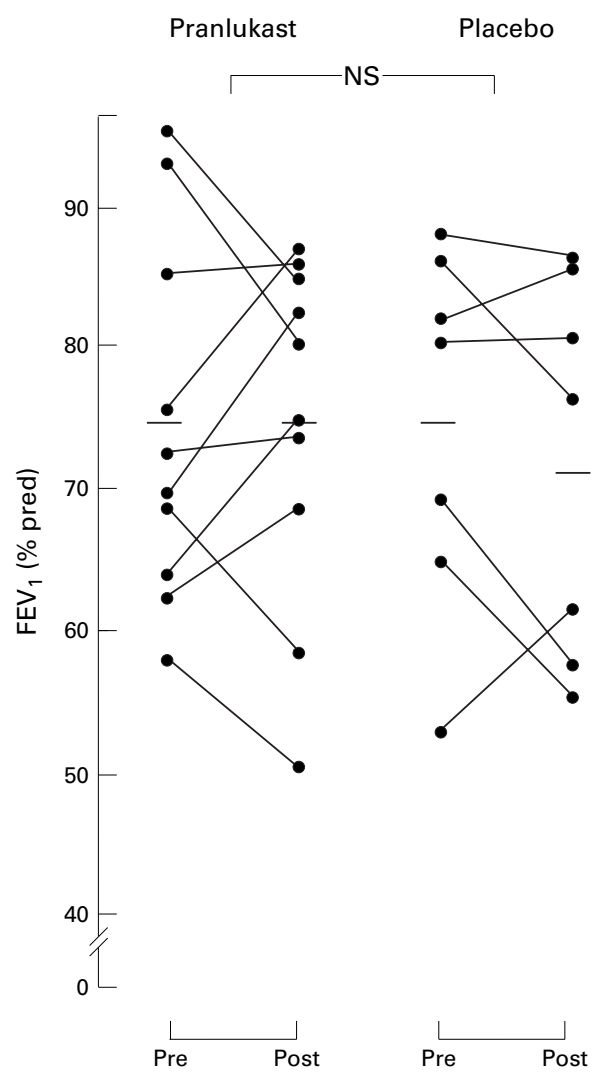

dilutions were inhaled by a De Vilbiss 646 nebuliser (De Vilbiss Co, Somerset, Pennsylvania, USA) at a constant flow rate of $5 \mathrm{l} / \mathrm{min}$. $\mathrm{FEV}_{1}$ was measured 10 minutes after administration of saline for two minutes to obtain the baseline value. For each of the antigens $\mathrm{FEV}_{1}$ was measured in the same way in ascending order of concentration and repeated 20,30, 60 and 120 minutes after inhalation of the highest concentration of each antigen. Reduction in $\mathrm{FEV}_{1}$ exceeded $20 \%$ in every patient.

All of the subjects were lifelong non smokers and none had any other serious lung disease as assessed by a chest radiograph obtained within one month before entry to the study. Patients with $\mathrm{FEV}_{1}$ of $<50 \%$ predicted were excluded.

\section{STUDY DESIGN}

The study was of a randomised parallel group design. Before entry the patients were instructed in the performance of spirometric tests according to American Thoracic Society

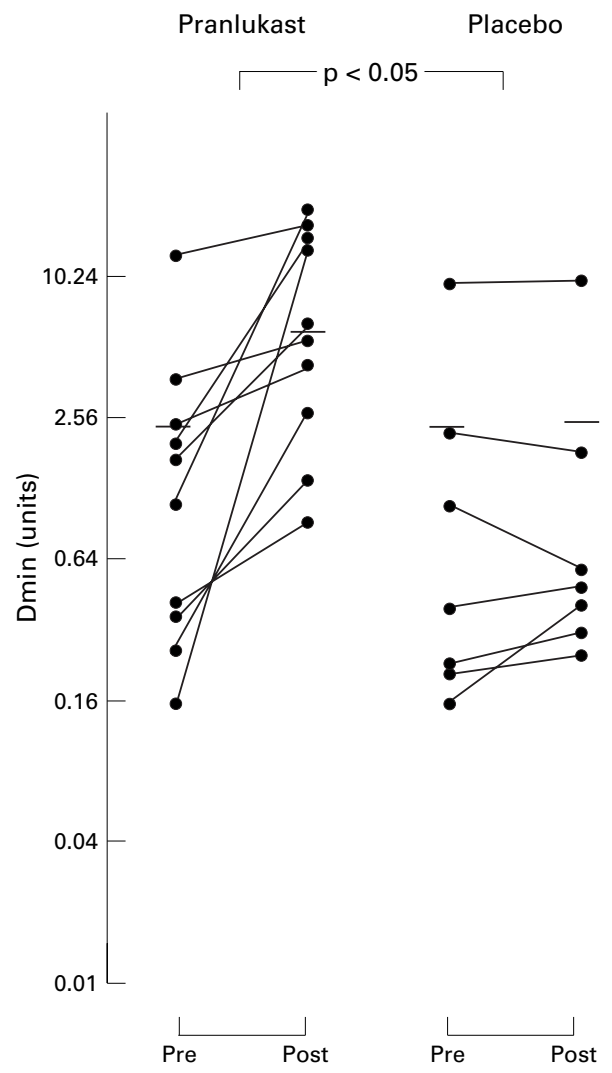

Figure 1 Percentage predicted forced expiratory volume in one second (FEV, and minimum dose of methacholine as a measure of bronchial responsiveness before and after treatment with pranlukast or placebo. Horizontal bars are mean values. 
Table 3 Number of cells per $\mathrm{mm}^{2}$ before and after treatment with pranlukast and placebo

\begin{tabular}{|c|c|c|c|c|c|c|c|}
\hline & \multicolumn{3}{|c|}{ Pranlukast $(n=10)$} & \multicolumn{3}{|c|}{ Placebo $(n=7)$} & \multirow[b]{2}{*}{$\begin{array}{l}\text { Estimated median } \\
\text { difference ( } 95 \% \text { CI) }\end{array}$} \\
\hline & Before & After & $\begin{array}{l}\text { Median } \\
\text { difference }\end{array}$ & Before & After & $\begin{array}{l}\text { Median } \\
\text { difference }\end{array}$ & \\
\hline $\mathrm{CD} 3$ & 88.5 & 64 & $28.5^{\star}$ & 110 & 125 & -10 & $-37(-69 \text { to }-1)^{\star}$ \\
\hline CD4 & 59 & 35.5 & $24^{\star}$ & 70 & 80 & -5 & $-28(-49 \text { to }-8)^{\star \star}$ \\
\hline CD8 & 42.5 & 34 & 10 & 40 & 45 & -5 & $-16(-56$ to 15$)$ \\
\hline CD68 & 62.5 & 55.5 & 16.5 & 110 & 120 & 8 & $-13(-33$ to 24$)$ \\
\hline NP57 & 16.5 & 16 & 3 & 17 & 18 & 0 & $0(-9$ to 17$)$ \\
\hline AA 1 & 26.5 & 12.5 & $11.5^{\star}$ & 47 & 50 & -3 & $-15(-26 \text { to } 0)^{\star}$ \\
\hline EG1 & 34.5 & 18 & 10.5 & 34 & 30 & 5 & $-9(-35$ to 20$)$ \\
\hline EG2 & 25.5 & 7 & $20.5^{\star \star}$ & 35 & 35 & -3 & $-18(-35 \text { to } 0)^{\star}$ \\
\hline$\gamma \mathrm{GTP}$ & 41.5 & 34 & 11 & 32 & 41 & 2 & $-5(-22$ to 22$)$ \\
\hline CD19 & 7 & 6 & 1.5 & 5 & 4 & 1 & $-1(-7$ to 2$)$ \\
\hline
\end{tabular}

${ }^{\star} \mathrm{p}<0.05 ;{ }^{\star \star} \mathrm{p}<0.01$.
AIRWAYS RESPONSIVENESS TO METHACHOLINE

The use of any bronchodilator was discontinued for 12 or more hours before the methacholine induced airway hypersensitivity was measured by the method of Takishima et $a l^{14}$ using an Astograph (Chest Co, Tokyo, Japan) direct writing recorder which gives doseresponse curves of respiratory resistance (Rrs) during continuous inhalation of methacholine in isotonic saline in stepwise incremental concentrations $(49,98,195,390,781,1563$, $3125,6250,12500$, and $25000 \mu \mathrm{g} / \mathrm{ml}$ ). Saline solution was inhaled first, followed after one minute by successive inhalations of increased concentration of methacholine. The minimum dose of methacholine (Dmin) was used as the indicator of bronchial sensitivity - that is, the amount of the cumulative dose at the point where the reciprocal of the Rrs decreased linearly. Dmin was scaled by a unit equal to one minute of a $1.0 \mathrm{mg} / \mathrm{ml}$ aerosol inhalation of methacholine.

\section{SCORING OF SYMPTOMS}

Six symptom scores were recorded daily on the diary card: (1) wheeze and (2) cough during the day using a graded scale as none $=0$, mild $=1$, moderate $=2$, severe $=3$; (3) amount of sputum graded as small $=1$, large $=2 ;(4)$ limitation of daily activity graded as none $=0$, mild $=1$, moderate $=2$, severe $=3 ;(5)$ nocturnal wheeze and (6) nocturnal cough graded as none $=0$, mild $=1$, moderate $=2$, severe $=3$. The results were expressed as the daily mean of the sums of the six scores. The mean initial symptom score was calculated from the scores and airway hypersensitivity were measured.

Pranlukast

Placebo

Pranlukast Placebo
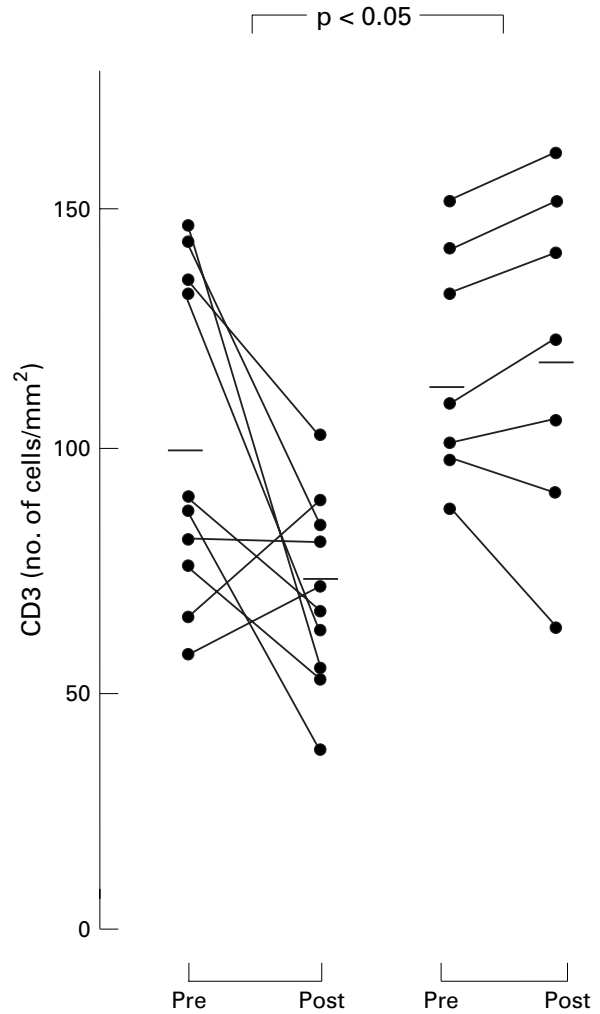
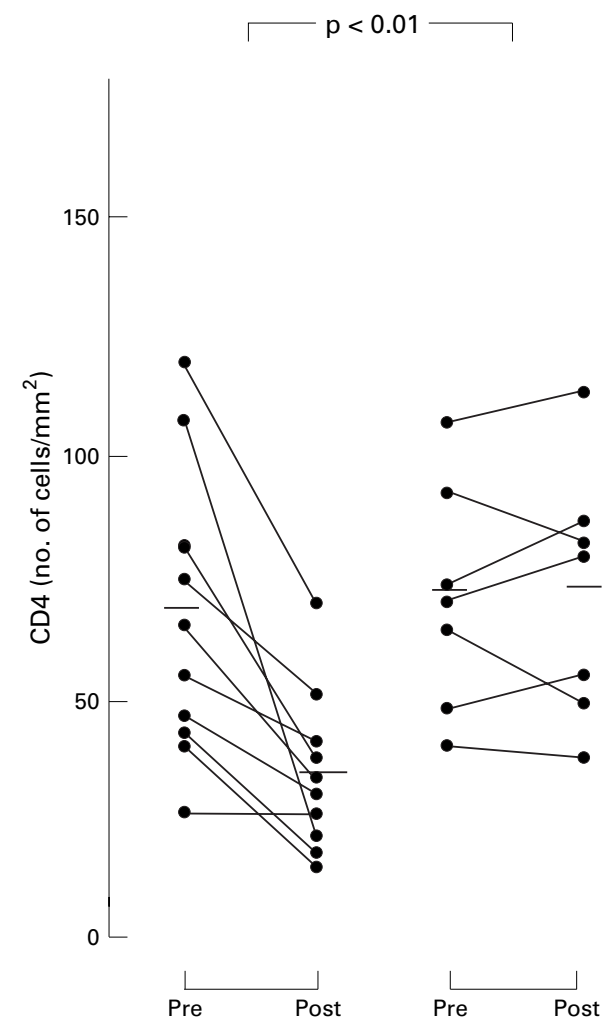

Figure 2 Individual T lymphocyte (CD3 and CD4) counts in the bronchial mucosa expressed as numbers of positive cells per square millimeter before and after treatment with pranlukast or placebo. Horizontal bars are mean values. 
Pranlukast Placebo
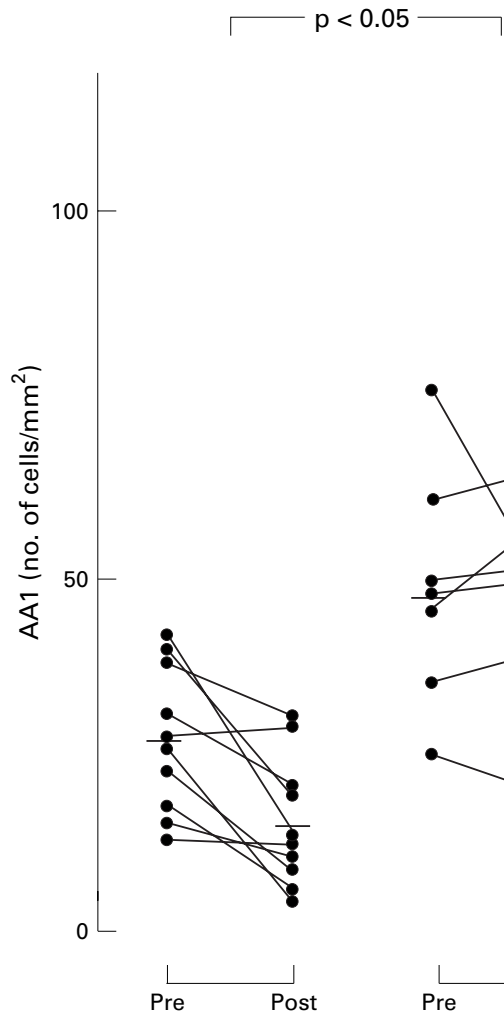
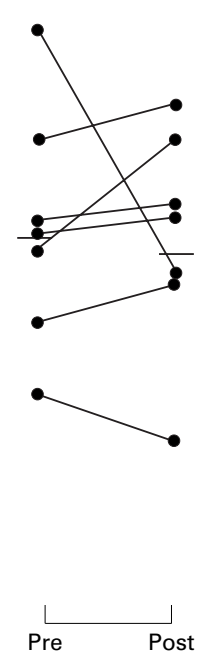

Pranlukast

Placebo

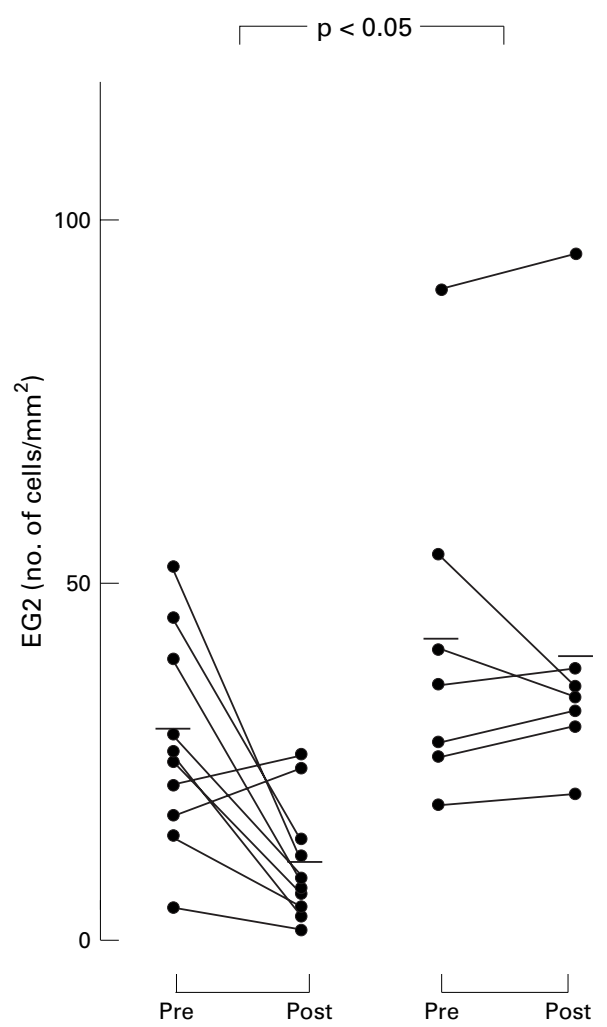

Figure 3 Individual mast cell (AA1) and eosinophil (EG2) counts in the bronchial mucosa expressed as numbers of positive cells per square millimeter before and after treatment with pranlukast or placebo. Horizontal bars are mean values.

recorded for the two week observation period. In the same way the mean symptom score after treatment was calculated from those recorded during weeks 3 and 4 of treatment.

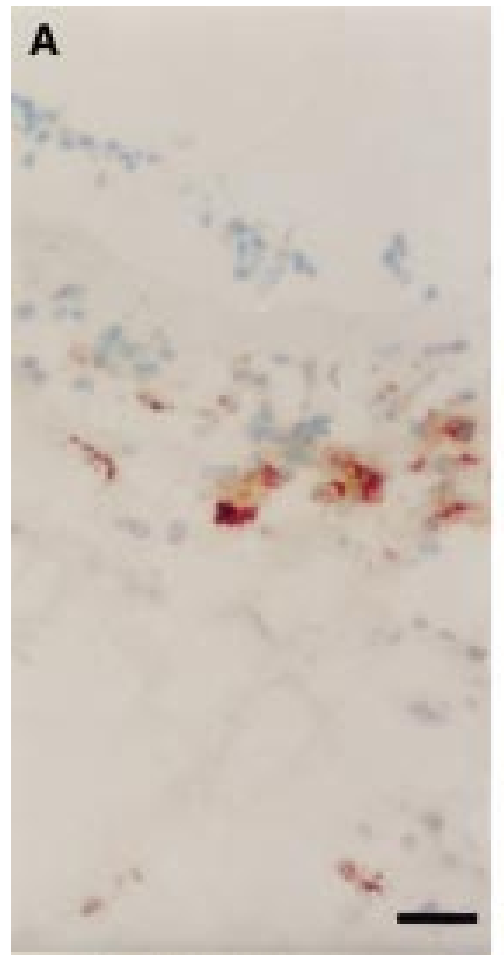

B

Figure 4 Biopsy specimen of bronchial mucosa stained for EG2 positive eosinophils $(A)$ before and (B) after treatment. Bar $=20 \mu \mathrm{m}$.
BIOPSY OF BRONCHIAL MUCOSA

Biopsy specimens were obtained during a bronchoscopy performed according to published guidelines. The patients were premedicated with atropine sulphate $(0.6 \mathrm{mg} \mathrm{im})$ and diazepam (5 mg iv) and two puffs $(200 \mu \mathrm{g})$ of salbutamol were then given using $4 \%$ lignocaine for local anaesthesia of the pharynx and the larynx. The bronchoscope (BF-20, Olympus Co, Tokyo, Japan) was inserted via the mouth following surface anaesthesia of the trachea and the bronchi with $2 \%$ lignocaine. Oxygen was administered via a nasal cannula at $41 / \mathrm{min}$ and the arterial oxygen saturation was monitored with a pulse oximeter (Biox 3740, Pulse Oximeter, Ohmeda, Louisville, Kentucky, USA). Using alligator forceps (FB-15C, Olympus) three bronchial biopsy specimens were obtained at the right main bronchus, the bifurcation of the right middle lobe; and the right $\mathrm{B}^{6}$ inlet. At the second bronchoscopic examination tissue samples were taken from the same site as on the first occasion.

\section{HISTOPATHOLOGICAL EXAMINATION}

The tissue specimens were covered in ornithine carbamyl transferase (OCT) compound, rapidly frozen in dry ice-acetone, and stored at $-70^{\circ} \mathrm{C}$ until further use. Specimens from all the tissues were stained with haematoxylin and eosin. Cryostat sections $(4 \mu \mathrm{m})$ were fixed for 15 minutes in cold acetone, washed five times with phosphate buffered saline (PBS) for five minutes, and then treated for 30 minutes with 
$10 \%$ normal porcine serum. The following monoclonal antibodies were then added and allowed to react for 60 minutes: CD3 (T cells), CD4 ("helper" $\mathrm{T}$ cells), and CD8 (suppressor T cells; Becton Dickinson, UK), CD68 (macrophages), NP57 (neutrophil elastase), AA1 (mast cell tryptase; Dako Ltd, UK), EG1 (Nichirei Ltd, Japan) and EG2 (Kabi Pharmacia, Uppsala, Sweden) which stain eosinophil for the cleaved form of eosinophilic cationic protein. Antibodies to $\gamma$ GTP (Cosmobio Ltd, Japan), an enzyme which metabolises leukotrienes, and CD19 (plasma cells; Becton Dickinson, UK) were also used. After washing with PBS, peroxidase-labelled anti-mouse immunoglobulin $\mathrm{G}$ (IgG) was added for one hour at room temperature, washed, and treated with $\mathrm{NaN}_{3}(65 \mathrm{mg} / \mathrm{dl})$ to prevent non-specific binding due to endogenous peroxidase in the eosinophils and neutrophils. The reaction was developed with 3,3'-diaminobenzidine (DAB). Sections were counterstained with methylene green before examination. For negative control the primary antibody was replaced by either non-specific rabbit immunoglobulin or PBS.

COUNTING OF POSITIVELY STAINED CELLS

The specimens were all coded and examined blind using a wide field microscope ( $\mathrm{BH} 2$, Olympus) at a magnification of $\times 400$. The observer counted the number of cells of the whole specimen. The stained cells were counted only in intact mucosa, excluding epithelium, mucosa, muscle and vessels. The contour of the tissue in which cells were counted was traced with computer software (NEC Co., Tokyo, Japan) on a video display (ITC-370, Olympus) and the area was calculated to determine the number of cells per unit area $\left(\mathrm{mm}^{2}\right)$ tissue. The within observer $\chi^{2}$ test for goodness of fit for five repeated counts $(\mathrm{df}=$ 4) was less than $5 \%$ for all the monoclonal antibodies studied.

STATISTICAL ANALYSIS

The mean symptom scores were calculated from the daily mean of the sum of the six symptoms both for the two weeks of the baseline period and for the last two weeks of the treatment period, during which time $\beta_{2}$ agonist use was also measured. The clinical response and cell counts during pranlukast treatment were compared with those during placebo using the Mann-Whitney $U$ test on the delta values (difference before and after treatment) for the two treatment groups. Results were expressed as the estimated median difference between delta values with $95 \%$ confidence intervals. The Wilcoxon matched pairs signed rank test was used to examine changes within groups. $p$ values of less than 0.05 were considered statistically significant.

\section{Results}

CLINICAL RESPONSE

Seventeen patients completed the study. Two patients (one from the pranlukast group and one from the placebo group) discontinued for personal reasons and two patients (both from the placebo group) discontinued because of an upper respiratory tract infection. There were no reported side effects during treatment. There were no significant differences in age, sex, total $\mathrm{IgE}, \mathrm{FEV}_{1}$ (\% predicted), and airway methacholine responsiveness between patients receiving pranlukast or placebo at baseline (table 1). The serum concentration of pranlukast ranged from 100 to $736 \mathrm{ng} / \mathrm{ml}$. Compared with placebo, decreases in $\beta_{2}$ agonist use and asthma symptom scores were observed with pranlukast treatment ( $<<0.01$; table 2$)$. No significant improvement in $\mathrm{FEV}_{1}$ was observed in patients treated with pranlukast (table 2, fig 1). Pranlukast treatment was accompanied by a decrease in airway responsiveness which was significant when compared with the change following placebo treatment $(\mathrm{p}<0.05$; table 2 , fig 1).

HISTOPATHOLOGICAL RESULTS

At baseline there were no significant differences between subjects receiving pranlukast and those receiving placebo in bronchial mucosal immunohistochemical tests for activation markers (table 3). Significant reductions in CD3, CD4, AA1, and EG2 positive cells were seen following treatment with pranlukast (figs 2 and 3), and there was also a significant reduction in the numbers of $\mathrm{CD} 3, \mathrm{CD} 4, \mathrm{AA} 1$ and EG2 positive cells compared with the placebo treated group. In contrast, changes in CD8 positive cells, CD68 (macrophage), NP57 (neutrophils), EG1, $\gamma$ GTP, and CD19 (plasma cells) within the pranlukast treated group were not significant and between group comparisons did not show significant differences. No significant changes were observed in cell numbers in biopsy specimens from the placebo treated group. Figure 4A and B illustrate the changes in the numbers of EG2 positive eosinophils from a single patient.

\section{Discussion}

In this double blind, placebo controlled study we have shown that decreased airways responsiveness in asthma after pranlukast treatment was accompanied by a decrease in the number of bronchial inflammatory cells in the airways. Pranlukast improves objective measurements of asthma compared with placebo, causing significant improvements in asthma symptom scores and a decrease in as needed $\beta_{2}$ agonist use.

An LTD4 antagonist, zafirlukast, has been shown to attenuate allergen induced bronchoconstriction and hyperreactivity in atopic asthmatic subjects. ${ }^{15}$ Selective antagonists of LTD4 and LTE4 only partially inhibit the antigen induced contraction of guinea pig trachea. ${ }^{1617}$ In contrast, pranlukast has been found to possess antagonist activity against LTC4 as well as LTD4 and LTE $4 .{ }^{12}$ Pranlukast also reduces antigen induced bronchoconstriction, airway hyperreactivity to acetylcholine, and pulmonary eosinophil accumulation in guinea pigs. ${ }^{18}$ The mean value of Dmin after the administration of pranlukast was significantly greater than the value after placebo administration, but the values of $\mathrm{FEV}_{1}$ were not altered by pranlukast. The mechanism by 
which the cysteinyl leukotrienes affect the human airway is not completely understood. However, the clinical improvements seen in patients receiving multiple dose pranlukast provide evidence to suggest that these leukotrienes act as mediators for asthma symptoms. In clinical trials of other leukotriene inhibitors treatment with zafirlukast and montelukast resulted in significant improvements in pulmonary function tests and decreases in asthma symptoms and use of $\beta$ agonists. ${ }^{19}{ }^{20}$ In a trial of zileuton (a 5-lipoxygenase inhibitor) patients receiving a dose of $2.4 \mathrm{mg} /$ day experienced significant improvements in airway function and hyperresponsiveness. ${ }^{21}$ This study indicated that pranlukast did not improve pulmonary function in asthmatic patients but it did improve bronchial hyperresponsiveness. Fujimura et $a l^{2}$ suggested that subthreshold concentrations of leukotrienes in the bronchial tissues, which have no effect on bronchomotor tone per se, may be involved in the development of bronchial hyperresponsiveness in asthma. The magnitude and precise mechanism of this effect on airway function and hyperresponsiveness require the investigation of long term clinical benefits of pranlukast.

It has been reported that cysteinyl leukotrienes induce eosinophilia in guinea pig airways and that the LTD4 receptor antagonist, MK- 571, significantly inhibits LTD4 and antigen induced eosinophil migration. ${ }^{23}$ However, no studies have examined the antiinflammatory effects of pranlukast on the bronchial mucosal cell infiltrate in asthma. In this placebo controlled study we observed a significant decrease in the number of EG2 positive eosinophils, AA1 positive mast cells, and $\mathrm{CD} 3$ and $\mathrm{CD} 4$ positive $\mathrm{T}$ cells. We are uncertain of the significance of the observed decrease in these inflammatory cells after treatment with LTC4, LTD4 and LTE4 receptor antagonist. It seems reasonable to speculate that, by stabilising eosinophils, pranlukast inhibits the release of some cytokines, thereby minimising eosinophil infiltration. Our data support this hypothesis as there was a significant reduction in activated eosinophils but no difference in EG1 positive eosinophils (or inactivated eosinophils). Most chemokines released from eosinophils with two N-terminal conserved cysteine residues in juxtaposition stimulate monocyte cytotoxic activity and upregulate adhesion molecules. They also augment $\mathrm{T}$ cell proliferation and cytokine production. We therefore assume that treatment with pranlukast inhibits the activation of eosinophils and the influx of inflammatory cells into the airways. The present study suggests that part of the beneficial effect of pranlukast might be related to its apparent ability to reduce the number of local inflammatory cells. Further studies on bronchoalveolar fluid concentrations of chemokines and leukotrienes after administration of pranlukast will be required.

Taniguchi and co-workers showed that treatment with pranlukast for one week did not alter percentage changes in respiratory resistance 10 minutes after challenge. However, they also showed that the treatment significantly re- duced percentage maximum changes in respiratory resistance, as well as percentage changes in these two indices 20-60 minutes after the exposure compared with placebo treatment. ${ }^{24}$ It is also reported that the maximal response occurred 4-16 minutes after inhalation of LTD4. In contrast, the maximal response was delayed and occurred 10-20 minutes after inhalation of LTC4. This is similar to the time required for significant amounts of bioconversion of LTC4 to LTD 4 by $\gamma$ GTP to occur in vitro. ${ }^{25}$ From these results we speculated that the effect of pranlukast may also be due to the inactivation of $\gamma \mathrm{GTP}$, resulting in the suppression of the production of LTD4 and taking 20 minutes to change respiratory resistance. However, our results suggest that treatment with pranlukast did not reduce the existing $\gamma$ GTP positive cells. The inhibitory activities of pranlukast may not be mediated by the blockade of $\gamma$ GTP activity but might occur through the direct interaction with LTC4, LTD4 and LTE4 receptors. Alternatively, it is possible that the power of this study may not have been sufficient to detect differences in $\gamma$ GTP positive cells.

With bronchial biopsy specimens we have been shown that pranlukast not only provided benefit in the treatment of asthma but also affected the number of different inflammatory cells.

We are indebted to Omar Ghaffar, Kuniharu Ono, Eleanor Minshall and Qutayba Hamid for editorial assistance.

1 Azzawi M, Bradley M, Jeffery PK. T lymphocytes and eosinophiles in bronchial biopsies in stable atopic asthma. Am Rev Respir Dis 1990;142:1407-13.

2 Darzen JM, Austen KF, Lewis RA, et al. Comparative airway and vascular activities of leukotrienes $\mathrm{C}-1$ and $\mathrm{D}$ in vivo and in vitro. Proc Natl Acad Sci 1980;77:4354-8.

3 Dahlen SE, Hedqvist P, Hammarstrom S, et al. Leukotrienes are potent constrictors of human bronchi. Nature 1980;288:484-6.

4 Hau XY, Dahlen SE, Lundberg JM, et al. Leukotrienes C4, D4 and E4 cause widespread and extensive plasma extravasation in the guinea pig. Naunyn Schmiedebergs Arch Pharmacol 1985;330:136-41.

5 Rinkema LE, Bemis KG, Fleisch JH. Production and antagonism of cutaneous vascular permeability in the guinea pig in reponse to histamaine, leukotrienes and A23187. F Pharmacol Exp Ther 1984;230:550-7.

6 Marom Z, Shelhamer JH, Bach MK, et al. Slow-reacting substances of anaphylaxis, leukotrienes C4 and D4, increase the release of mucus from human airways in vitro. Am Rev Respir Dis 1982;126:449-51.

7 Wardlaw AJ, Hay H, Cromwell O, et al. Leukotrienes, LTC4 and B4 in bronchoalveolar lavage in bronchial asthma and respiratory diseases. F Allergy Clin Immunol 1989;84:19-26.

8 Lam S, Cham H, LeRiche JC, et al. Release of leukotrienes in patients with bronchial asthma. $\mathcal{F}$ Allergy Clin Immunol 1988;81:1711-7.

9 Taylor GW, Taylor I, Black P, et al. Urinary leukotriene E4 after antigen challenge in acute asthma and in allergic rhinitis. Lancet 1989;i:584-8.

10 Okubo T, Takahashi H, Sumitano M, et al. Plasma levels of leukotrienes C4 and D4 during wheezing attack in asthmatic patients. Int Arch Allergy Appl Immunol 1987;84: $149-55$.

11 Ferreri NR, Howland WC, Stevenson DD, et al. Release of leukotrienes, prostaglandins and histamine into nasal secreation of aspirin-sensitive asthmatics during reaction to aspirin. Am Rev Respir Dis 1988;137:847-54

12 Obata $T$, Okada $Y$, Motoishi $M$, et al. In vitro antagonism of ONO-1078, a newly developed anti-asthma agent, against peptide leukotrienes isolated guinea pig tissues. Fapan $\mathcal{F}$ Pharmacol 1992;60:227-37.

13 American Thoracic Society. Standards for the diagnosis and care of patients with chronic obstructive pulmonary disease (COPD) and asthma. Am Rev Respir Dis 1987;136:225-44. recorder of the dose-response curves of the airway to methacholine. Chest 1981;80:600-6.

15 Taylor IK, O'Shaughnessy KM, Fuller RW, et al. Effect of cysteinyl-leukotriene receptor antagonist ICI 204,219 on allergen-induced bronchoconstriction and airway hyperreactivity in atopic subjects. Lancet 1991;337:690-4. 
16 Snyder DW, Cho HL, Gilmore J. Endogenously formed leukotriene C4 activates LTC4 receptors in guinea pig trachea政

17 Redkar-Brown DG, Aharony D. Inhibition of antigeninduced contraction of guinea pig trachea by ICI 198,615 Eur F Pharmacol 1989;165:113-21.

18 Nakagawa N, Obata T, Kobayashi $\mathrm{T}$, et al. Effect of a peptide leukotriene receptor antagonist, ONO-1078, on guinea-pig models of asthma. Eur $\mathcal{F}$ Pharmacol 1993;235 211-9.

19 Spector SL, Smith LJ, Glass M, the Accolate Asthma Trialist Group. Effects of six weeks of therapy with oral doses of ICI 204,219, a leukotriene D4 receptor antagonist, in subjects with bronchial asthma. Am f Respir Crit Care Med 1994; 150:618-23.

20 Reiss TF, Altman LC, Chervinsky P, et al. Effect of montelukast (MK-0476), a new potent cysteinyl leukotriene (LTD4) receptor antagonist, in patients with chronic asthma. F Allergy Clin Immunol 1996;98:528-34.
21 Israel E, Rubin P, Kemp JP, et al. The effect of inhibition of 5 -lipoxygenase by zileuton in mild to moderate asthma. Ann Intern Med 1993;119:1059-66.

22 Fujimura M, Sakamoto S, Kamio Y, et al. Effect of a leukotriene antagonist, ONO-1078, on bronchial hyperresponsiveness in patients with asthma. Respir Med 1993;87:1338.

23 Foster A, Chan CC. Peptide leukotriene involvement in pulmonary eosinophil migration upon antigen challenge in the
actively sensitized guinea pig Int Arch Allergy Appl Immunol 1991;96:279.

24 Taniguchi Y, Tamura G, Honma M, et al. The effect of an oral leukotriene antagonist, ONO-1078, on allergeninduced immediate bronchoconstriction in asthmatic subjects. f Allergy Clin Immunol 1993;92:507-12.

25 Drazen JM. Comparative contractile responses to sulfidopeptide leukotrienes in normal and asthmatic human subjects. Ann NY Acad Sci 1988;524:289-97. 